\title{
Trace Metals and Diatom Stratigraphy along the Sill between Lakes Telaga Warna and Telaga Pengilon, Dieng, Central Java, Indonesia
}

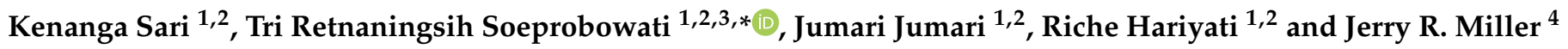 \\ 1 Center for Paleolimnoloy (CPalim), Universitas Diponegoro, Semarang 50241, Indonesia; \\ ksari.ken@gmail.com (K.S.); jumariundip@gmail.com (J.J.); riche.hariyati@gmail.com (R.H.) \\ 2 Department Biology, Faculty of Science and Mathematics, Universitas Diponegoro, \\ Semarang 50275, Indonesia \\ 3 School of Postgraduate Studies, Universitas Diponegoro, Semarang 50241, Indonesia \\ 4 Department of Geosciences and Natural Resources, Western Carolina University, Cullowhee, NC 28723, USA; \\ jmiller@email.wcu.edu \\ * Correspondence: trsoeprobowati@live.undip.ac.id
}

Citation: Sari, K.; Soeprobowati, T.R.; Jumari, J.; Hariyati, R.; Miller, J.R. Trace Metals and Diatom Stratigraphy along the Sill between Lakes Telaga Warna and Telaga Pengilon, Dieng, Central Java, Indonesia. Sustainability 2021, 13, 3821. https://doi.org/ $10.3390 /$ su13073821

Academic Editors: Ozgur Kisi

Received: 2 December 2020

Accepted: 17 March 2021

Published: 31 March 2021

Publisher's Note: MDPI stays neutral with regard to jurisdictional claims in published maps and institutional affiliations.

Copyright: (c) 2021 by the authors. Licensee MDPI, Basel, Switzerland. This article is an open access article distributed under the terms and conditions of the Creative Commons Attribution (CC BY) license (https:// creativecommons.org/licenses/by/ $4.0 /)$.

\begin{abstract}
This study examines the spatiotemporal variations in diatom assemblages and selected metal concentrations $(\mathrm{Pb}, \mathrm{Cr}, \mathrm{Cd}, \mathrm{Al}$, and $\mathrm{Zn}$ ) in bed sediments of lakes Telaga Pengilon and Telaga Warna in Dieng, Indonesia to document natural and/or anthropogenic changes in the local aquatic and terrestrial environment. The analyses focused on sediments collected from a $150-\mathrm{cm}$ core taken from a sill between the two lakes, which exhibit significant differences in water chemistry. The core was subdivided into 14 stratigraphic intervals allowing for an analysis of the vertical (and temporal) variations in diatom composition and selected metal concentrations. A total of 103 taxa from 25 genera were identified in the core. Diatom assemblages were dominated by Eunotia (56\%), Pinnularia (17.2\%), and Frustulia (4.6\%). The most abundant species was Eunotia, a diatom that can tolerate a wide range of $\mathrm{pH}$ conditions. Given that $\mathrm{pH}$ within waters of the two lakes differs significantly, the abundance of Eunotia suggests that $\mathrm{pH}$ in the area between Telaga Pengilon and Telaga Warna varied through time, potentially ranging from about 2.5 to 8 . Changes in $\mathrm{pH}$ were likely related to alterations in hydrological conditions. Metal concentrations varied with depth/time of deposition within the core. Peak metal concentrations appear to be related to the influx of debris from a volcanic eruption. Based on the principle component analysis (PCA), the input of volcanic materials also influenced diatom assemblages and resulted in a distinct layer of broken diatom frustules. Relatively low metal concentrations in surface sediments suggest that the erosion of hillslope soils in response to agricultural activity did not significantly impact the lakes.
\end{abstract}

Keywords: diatom; heavy metals; Telaga Warna; Telaga Pengilon; Dieng

\section{Introduction}

Indonesia is an archipelago that has 130 active volcanos, including those associated with the Dieng plateau, a plateau located about $2100 \mathrm{~m}$ above sea level within the regencies of Wonosobo and Banjarnegara. Many of the volcanic craters in the Dieng plateau have a history of explosive eruptions that have led to the significant loss of human life [1,2].

Lakes within the Dieng plateau, including lakes Telaga Warna and Telaga Pengilon, have primarily been produced by the collapse of volcanic calderas following eruptions that released massive amounts of lava, volcanic ash, and rocks. Once formed, these depressions are rapidly filled by rainfall and runoff associated with Indonesia's humid tropical climate [1,3].

Telaga Pengilon and Telaga Warna are both small lakes that have become particularly significant tourist destinations, and the area has been named a conservation area due to the presence of several endemic species, including Alcedinidae, Ictinaetus malayanensis 
(black eagle), Oriolus chinensis (black-napedoriole), Anas superciliosa (black duck), and Gallinulla chloropus (moorhen). The area that surrounds both lakes is an important habitat for terrestrial biota and has been defined as a National Sanctuary (based on Wonosobo Regional Rule no. 1/1996), and as a conservation area based on Regional Rule no. 1/2004, and Wonosobo Regional Rule no. 2/2011 [4,5].

The two lakes are located adjacent to one another in a volcanic crater, but their waters are separated by a low relief lava flow (or sill). The lava flow is covered by grass and possesses areas of wetlands. The ecological characteristics of the lakes also differ from other lakes in the region and, perhaps more importantly, from one another $[5,6]$. The $\mathrm{pH}$ of lake Telaga Warna is acidic, ranging from about 2.2 to 5.4 [6]. The ongoing volcanic activity beneath and adjacent to Telaga Warna locally creates gas bubbles that rise to the lake surface [7-9]. In contrast, Telaga Pengilon is a clear water lake, devoid of the colors and high mineral content associated with Telaga Warna. The $\mathrm{pH}$ of the water in Telaga Pengilon is around 6. It is characterized by a surface area of about 7.8 ha, and a depth of around $18 \mathrm{~m}[7,8]$.

Lakes Telaga Warna and Telaga Pengilon are famous in the Dieng area since their waters reflect differing colors that contrast with other lakes in the region. The colors in the lakes change unpredictably, alternating between blue, green or red depending on the concentration of hydrogen sulfide, sulfur dioxide, organic carbon, chloride, and other minerals in the water. In addition, the lake waters are affected by the reflection from sunlight from their surface, which is influenced by the amount of limestone and quartz within the water column [5]. In combination, the lake waters are considered a valuable natural resource and tourist attraction. Potatoes are the most important agricultural commodity in Dieng, local yields average around 16.6 tons/ha $[10,11]$. The annual rain fall within the Dieng plateau reaches $3917 \mathrm{~mm}$ /year, which when combined with locally high slopes $(>40 \%)$ and increasingly high rates of land change for agriculture purposes since 1970 , has produced up to $9.2 \mathrm{~kg} / \mathrm{m}^{2}$ of erosion $[12,13]$.

Since the beginning of the nineteenth century, agriculture (combined with other human activities) has been increasing within the Dieng plateau, and is thought to negatively impact the aquatic environment. Although agricultural activity within the Telaga Warna and Telaga Pengilon lake basin has been limited to date, its potential impacts on lake waters has become a concern. The hydrology of the lakes is also impacted by the uncontrolled pumping for irrigation and other human activities, and has reduced lake water levels during the dry season [14].

Studies of $\mathrm{Pb}, \mathrm{Cr}, \mathrm{Cd}$, and $\mathrm{Zn}$ concentrations are often analyzed in lacustrine environments located in highly urbanized areas with dense populations such as Dieng to assess sediment and water quality. These studies generally rely, as noted earlier, on documented vertical variations in metal concentrations to determine (1) background concentrations of metals prior to significant human activities, and (2) changes in metal loadings to the lake through time.

Freshwater lake bed sediments in high mountainous areas also possess, in many instances, excellent records of ecological change. Thus, the analysis of their sedimentary deposits can be used to assess the ecological status through time of both the local terrestrial ecosystem and the lake itself $[15,16]$. Pollen and other aquatic biota, such as benthic diatoms, have been particularly useful for the assessment of lacustrine ecosystems.

Diatoms are microscopic organisms that are an abundant, diverse, and important component of algal assemblages which are widely distributed in water bodies and dominate many aquatic environments [17-19]. Diatoms have been widely used as biomonitoring due their sensitivity to respond to environmental change, and diatom assemblages are usually diverse and therefore contain considerable ecological information [20-22]. When diatoms die, their remains settle onto the lake bottom, where, due to their cell wall is made from silica that allows them to be preserved in sediment for long periods, they are preserved in the bottom sediments. Thus, the ornamentation on the cell wall allows for the microscopic identification to the genus and/or species level. This allows diatom abundance 
and diversity to be used to assess changes in water quality and other environmental conditions [23-25].

In this study, diatoms from a long-term core extracted from the sill between lakes Telaga Warna and Telaga Pengilon, were used in conjunction with environmental variables to investigate the effects of selected heavy metal on the diatom community structure. Inherent in the approach was: (1) An analysis of the temporal changes in the composition and biodiversity of benthic diatoms in the area between Telaga Warna and Telaga Pengilon, (2) a temporal analysis of the variations in the influx of selected metals to the lakes, and (3) an interpretation of the potential causes of variation in environmental conductions during the deposition of the sill's upper $1.5 \mathrm{~m}$ of sediment.

\section{Materials and Methods}

\subsection{Study Area}

The Dieng plateau, located in Wonosobo, Central Java, is located about $2096 \mathrm{~m}$ above sea level. The elongate, northwest-southeast trending plateau is approximately $14 \mathrm{~km}$ long and $6 \mathrm{~km}$ wide. Climatically, it is characterized by a humid, wet, subtropical climate. The average annual rainfall is $2652 \mathrm{~mm}$, most of the precipitation falls between November and March. The average daily temperatures are relatively constant $\left(\sim 14^{\circ} \mathrm{C}\right)$, but can reach values near $0{ }^{\circ} \mathrm{C}$ during the dry season. Geologically, it is underlain by a variety of rock types, including limestones, tuffaceous sandstones, and volcanic assemblages, including basalts and basaltic andesite. Geomorphologically, the Dieng plateau is a volcanically hazardous and complex landscape consisting of late Quaternary to recent volcanic stratocones, vents and craters, the more recent features possess a history of recurrent phreatic eruptions and the emission of poisonous gases [26,27]. The prominent volcanic features are associated with the Dieng volcanic complex which consists of late Quaternary to recent volcanic deposits.

Lakes in Dieng, in general, are formed in volcanic craters with a relatively high acidity caused by the influx of volcanic gases, and high concentrations of magnetic volatiles, such as $\mathrm{SO}_{2}, \mathrm{H}_{2} \mathrm{~S}, \mathrm{HCl}$, and $\mathrm{HF}$. Lake Telaga Warna is a representative example, and is currently enriched (134 to $240 \mathrm{ppm}$ ) in dry gas (up to $90 \% \mathrm{H}_{2} \mathrm{O}$ and lesser amounts of $\mathrm{CO}_{2}, \mathrm{SO}_{2}$, and $\mathrm{SO}_{4}$ ) and around $1.6 \mathrm{ppm} \mathrm{H}_{2} \mathrm{~S}[2,28]$. These constituents have created acidic, extremely low $\mathrm{pH}$ conditions that are exacerbated by evaporation during periods of limited rainfall. In contrast, lake Telaga Pengilon generally exhibits a $\mathrm{pH}$ of around 6 and possesses a high concentration of minerals. However, $\mathrm{pH}$ is influenced and varies in response to significant precipitation during the 6-month rainy season.

The area along the corridor between lakes Telaga Warna and Telaga Pengilon was selected as a study area (Figure 1), in part, since it was considered representative of a relatively undisturbed area within the plateau. In comparison to other lakes on the plateau, agriculture is relatively limited within the lake basin. The study focuses on a sediment core that was extracted from the divide (or sill) between the two lakes. The sill is characterized by hydrologic conditions characterized by shallow water, about 1-2 $\mathrm{m}$ deep during the wet season, surrounded by an undulating terrain covered with Actinoscirpus grossus (a grass) and other macrophytes.

A small channel traverses the sill and hydrologically connects the two lakes, at least during the rainy season. Water along the corridor (sill) is composed of a mixture of both acidic and slightly alkaline to neutral waters derived from both lakes Telaga Warna and Telaga Pengilon, respectively. During the rainy season, the area is completely flooded as a result of increased water volumes from both lakes, and flooding is expected to influence the rate of diatom growth. The average annual water temperature at the site was $21.5^{\circ} \mathrm{C}$, whereas the elevation of the sill is about 2088 masl. 

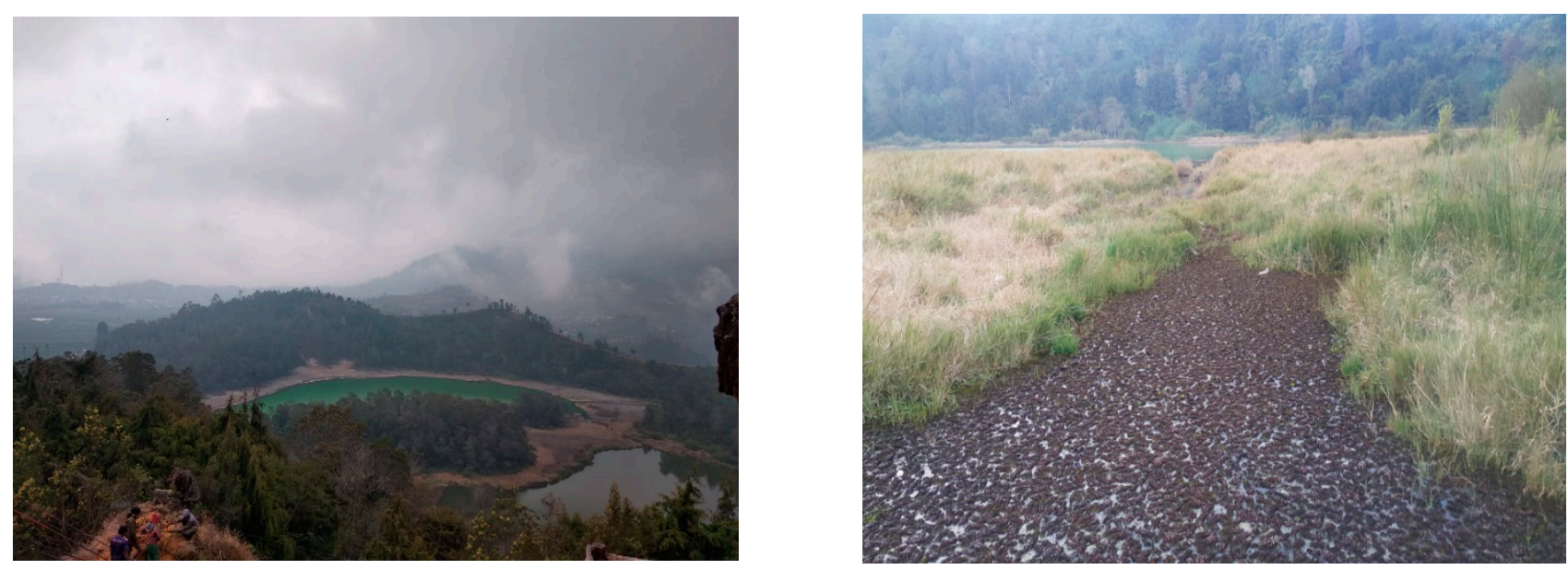

Figure 1. Coring site along the sill between lakes Telaga Pengilon and Telaga Warna in Dieng (left) and the channel that flows from Telaga to Warna (right).

\subsection{Sediment and Core Collection}

A sediment core from the wetland between the two lakes was obtained using a manual coring device near the mid-point of the divide (sill) and within the deepest part of the wetland area $\left(07^{\circ} 12.904^{\prime} \mathrm{S}, 109^{\circ} 54.894^{\prime} \mathrm{E}\right)$. The extracted core was $150 \mathrm{~cm}$ long. Upon collection, the core was described and subsequently sampled at approximately $10 \mathrm{~cm}$ intervals for diatom and geochemical analyses.

\subsection{Diatom and Geochemical Analyses}

Once in the laboratory, the sediment samples were allowed to air dry for 3 days before they were digested to extract the diatoms. All diatom samples were oxidized following a procedure modified from Battarbee et al. [29] and outlined in Soeprobowati et al. [3]. The procedure involved the hot acid digestion of the sediments with $10 \% \mathrm{HCL}$ and $10 \%$ $\mathrm{H}_{2} \mathrm{O}_{2}$, during which time the sample was heated for $2 \mathrm{~h}$ at $>80^{\circ} \mathrm{C}$. Following digestion, the sample was washed with distilled water. This process was repeated three times, after which the samples were allowed to sit overnight to allow the natant to be effectively separated from the supernatants (the acidic solution could be removed). Washing of the sediment was then repeated several times until its $\mathrm{pH}$ was neutral.

A microscopic slide of the sample was prepared using an evaporation procedure in which $400 \mu \mathrm{L}$ was dropped on the coverslip. It was then dried on the hotplate and mounted to the slide with Naphrax. Identification of the diatoms was performed using a light microscope at 1000 magnification, and a minimum of 400 diatom valves was enumerated and counted [5]. Diatom taxonomy for species followed the methods put forth by [30-39], and were checked in the Algabase.org database [40].

Sediment samples were analyzed for selected metals, including lead $(\mathrm{Pb})$, cadmium $(\mathrm{Cd})$, chromium $(\mathrm{Cr})$, zinc $(\mathrm{Zn})$, and aluminum (Al). The four trace metals $(\mathrm{Pb}, \mathrm{Cd}, \mathrm{Cr}$, and $\mathrm{Zn}$ ) were selected as they are commonly abundant in volcanic rocks, and (in the case of $\mathrm{Zn}$ ) it was associated with the utilized agricultural fertilizers. Aluminum is one of the most abundant naturally-occurring metals, and is often wide spread in the environment. However, it was analyzed here since it is enriched in the B- and C-horizon of the upland tropical soils in the form of oxides and hydroxides. Thus, when combined with its generally low solubility under normal $\mathrm{pH}$ and Eh conditions and its association with clay minerals, it was thought to serve as a potential tracer of eroded upland soils.

The selected metals were analyzed using a slightly modified version of USEPA Method 200.7. This multi-step analysis involved the digestion of $200 \mathrm{mg}$ of dried and homogenized sediment, $<2 \mathrm{~mm}$ in size, in $125 \mathrm{~mL}$ polypropylene screw-top bottles containing $4 \mathrm{~mL}$ of aqua regia $\left(3: 1 \mathrm{HNO}_{3}\right.$ to $\left.\mathrm{HCl}\right)$. The bottles were sealed and held at $90{ }^{\circ} \mathrm{C}$ in a water bath for $60 \mathrm{~min}$. The leaches were then transferred to $100 \mathrm{~mL}$ volumetric flasks and 
brought up to volume with ultra-pure deionized water. The samples were analyzed by Inductively Coupled plasma optical emission spectroscopy (ICP-OES) (Perkin Elmer Optima 4100DV ICP-OES) on the campus of Western Carolina University (USA). The platform was calibrated with USGS standard reference materials GXR-1, GXR-2, and GXR-5 and NIST standard reference materials 2709 and 2711. Along with a reagent blank, the analyte concentrations for these five SRMs were plotted against blank-subtracted integrated peak areas. A regression line was fitted to the calibration points and the equation of the line was used to quantify unknown sample concentrations. Deviation of standards from this regression line was used to estimate analytical accuracy, replicate analyses were used to determine analytical precision, and analyses of reagent blanks are used to estimate lower limits of detection. Precision and accuracy were generally within $+/-5 \%$.

\subsection{Data Analysis}

Environmental and diatom data were analyzed using different multivariate methods. Species with a relative abundance of $<2 \%$ were removed from the statistical analysis. The diatom assemblage was graphed using the software package $C 2$ version 1.7.7 [41]. Diatom data were transformed as $\log (x+1)$ to stabilize the variance, and tested for normality. The principal component analysis (PCA) was conducted to identify the major environmental variables that influenced the data set, and to determine the relationship between metal variables and diatom species. In addition, Pearson correlation analyses $(p<0.05$ and $p<0.01$ levels) were also conducted on the five metals $(\mathrm{Pb}, \mathrm{Cd}, \mathrm{Cr}, \mathrm{Zn}$, and $\mathrm{Al})$. These analyses were performed using the RStudio software [42]. The hierarchical cluster analysis was applied using the unweighted pair group method with an arithmetic mean (UPGMA) [43]. The results show diatom zones based on assemblages with similar Bray Curtis similarity species as analyzed using PAST version 3.1.5 [44].

\section{Results}

\subsection{Vertical Distribution of Diatoms}

A total of 103 different species of diatoms belonging to 25 genera were recorded in 14 samples from the core. There were 11 dominant taxa that exceeded a $2 \%$ relative abundance, the threshold was required to be included in the statistical analyses. A large group of diatoms, especially genus Eunotia, comprised approximately $56 \%$ of the total diatom community, whereas $17.2 \%$ were comprised of Pinnularia, and $4.7 \%$ of Frustulia. In general, Eunotia formica (Ehrenberg) was the dominant diatom within nearly all strata, exhibiting an abundance of $25 \%$. Eunotia monodon var. tropica (Lange-Bertalot) comprised $20.97 \%$ of the total diatom assemblages. A cluster analysis was performed on those species that comprised more than $2 \%$ of the total. The analysis subdivided the strata in the sediment core into four diatom zones (Figure 2).

\subsection{Zone I $(150-110 \mathrm{~cm})$}

Zone I (150-110 cm) was located at the bottom of the core and dominated by $E$. monodon var. tropica (Lange-Bertalot). The abundance of $E$. monodon var. tropica (LangeBertalot) fluctuated between $2.75 \%$ and $17 \%$, which is associated with E. formica (Ehrenberg), Pinnularia gibba (Ehrenberg), and Eunotia sulcata (Hustedt). Moreover, the abundance of Brachysira brebissonii (Ross) (5.9\%) was higher than any other zone. E. monodon var. tropica (Lange-Bertalot) is a cosmopolitan species distributed across Indonesia and South Asia.

\subsection{Zone II $(110-96 \mathrm{~cm})$}

Zone II is characterized by poor, but variable diatom preservation between the sediment layers. Diatom frustules were abundant and well preserved in the upper layer, while at a depth below $102 \mathrm{~cm}$ the diatom valves were highly broken. Only broken frustule of $E$. monodon var. tropica (Lange-Bertalot) and E. formica (Ehrenberg) were found. 


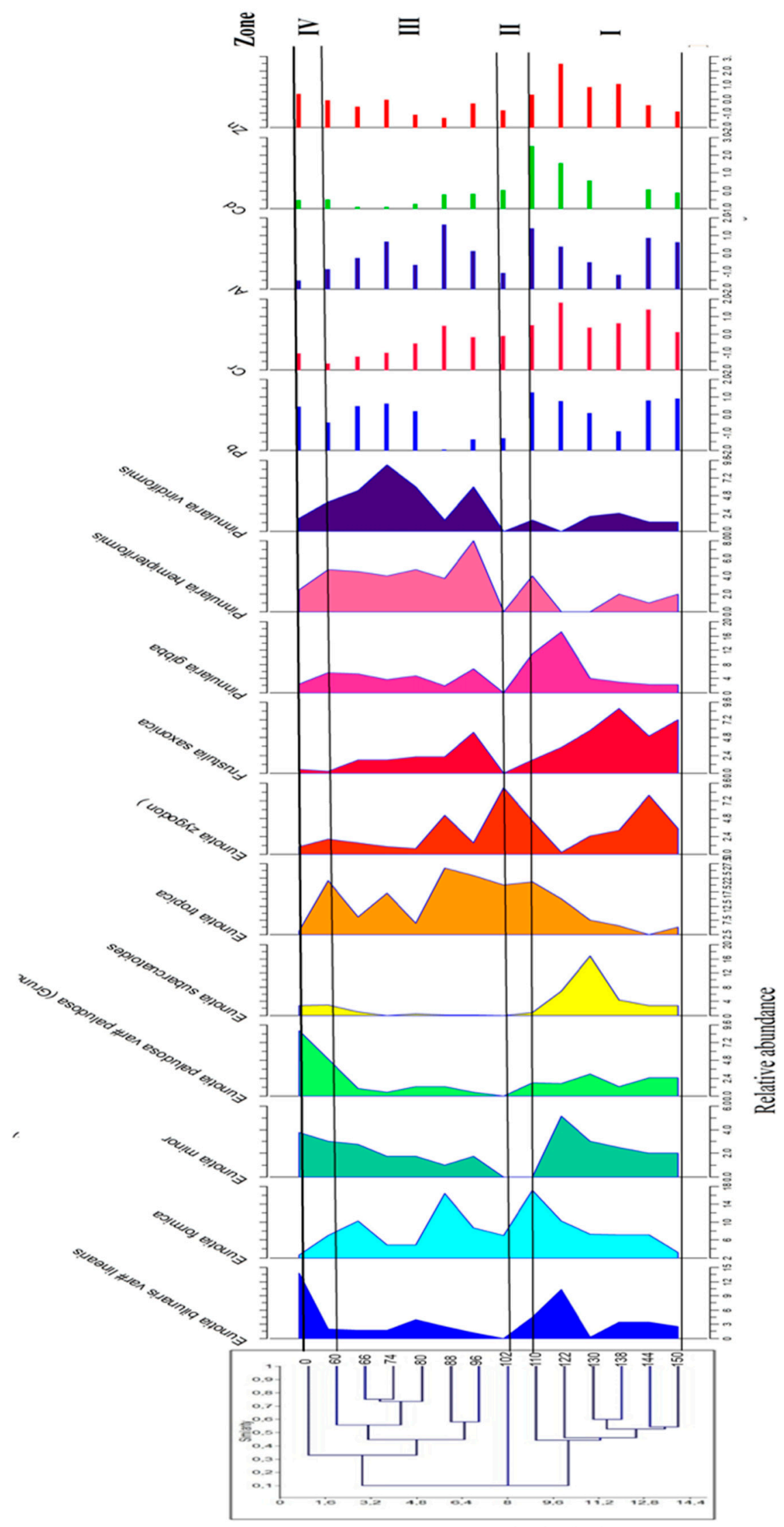

Figure 2. Trace metals and diatom stratigraphy along the sill between lakes Telaga Warna and Telaga Pengilon in Dieng. 


\subsection{Zone III $(96-60 \mathrm{~cm})$}

Zone III $(96-60 \mathrm{~cm})$ is dominated by E. formica (Ehrenberg), Pinnularia viridiformis (Nitzsch), and Pinnularia viridis (Nitzsch). The abundance of Achanthes increased by about 6\%, whereas Fragillaria and Aulacoseira increased above the abundances observed in the previous zones (below). The high abundance of Eunotia and periphytic species in the middle of the core also indicates a higher water level associated with higher $\mathrm{pH}$ conditions. Eunotia has the ability to respond to $\mathrm{pH}$ and some Eunotia have been found in the extremely acidic conditions.

\subsection{Zone IV $(60-0 \mathrm{~cm})$}

Zone IV $(60-0 \mathrm{~cm})$ is dominated by E. bilunaris var. linearis (Ehrenberg) $(\sim 14 \%)$, E. bilunaris var. mucophila (Lange-Bertalot) (11.75\%), E. curvata (Kutzing) $(\sim 12 \%)$, and E. incisa (Gregory). All of these species are widely distributed on a global scale. The majority of these benthic diatoms consist of small taxa belonging to the genera Achnanthes (five species), Navicula (seven species), Fragilaria (three species), and the acidic-tolerant genera Eunotia (26 species).

\subsection{Variations in Metal Concentrations}

In general, $\mathrm{Al}, \mathrm{Cd}, \mathrm{Pb}$, and $\mathrm{Zn}$ concentrations were relatively high at the bottom of diatom Zone I. Their concentrations decreased in the middle of Zone I, before reaching maximum concentrations at the top of Zone I and the bottom of Zone II. Concentrations of these metals then decreased sharply at the top of diatom Zone II (Figure 2). Zinc and $\mathrm{Cd}$ concentrations remained low through the remainder of Zones III and IV, whereas $\mathrm{Cr}$ and $\mathrm{Al}$ concentrations increased slightly before declining towards the surface. Lead also increased slightly at the top of Zone I and bottom of Zone II, before remaining relatively constant through the remainder of the core. $\mathrm{Zn}$ was the only metal to show an increase in the surface sediments, although the increase was limited (Figure 2).

The relationships between the metals in the 14 subsamples of the core were analyzed using the principal component analysis (PCA) (Figure 3). The first three principal components (PCs) explained $80.35 \%$ of the total variance. Component 1 explained up to $41.14 \%$ of the total variance and was characterized by high loadings of $\mathrm{Cd}(0.55)$ and $\mathrm{Cr}(0.51)$. Component 2 explained $22.79 \%$ of the total variance and was dominated by weighted values for $\mathrm{Zn}(0.58)$ and $\mathrm{Pb}(0.28)$, particularly at a depth of $66 \mathrm{~cm}$ (diatom Zone I). Most of the subsamples were located in the opposite quadrant from $\mathrm{Cd}$ and $\mathrm{Cr}$ (Figure 4), which were concentrated at a depth of $144 \mathrm{~cm}$.

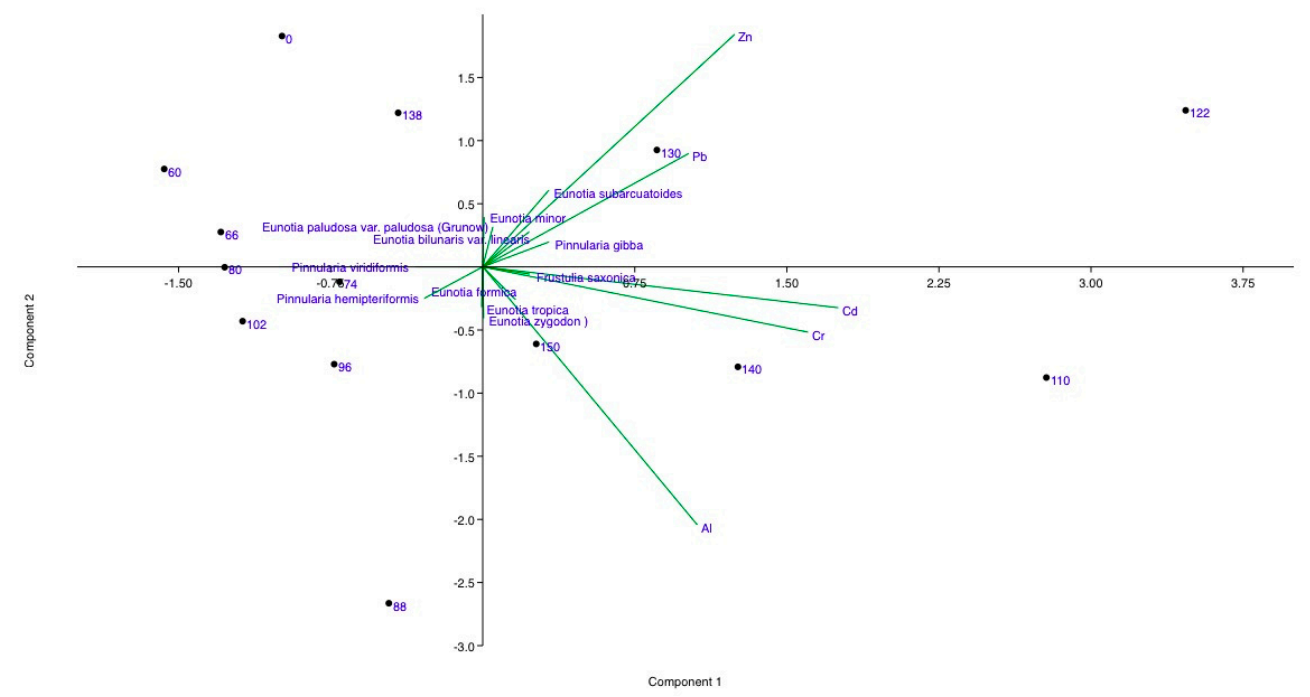

Figure 3. Environmental parameter that contributed to the community of diatom, resulting from the principal component analysis (PCA). 


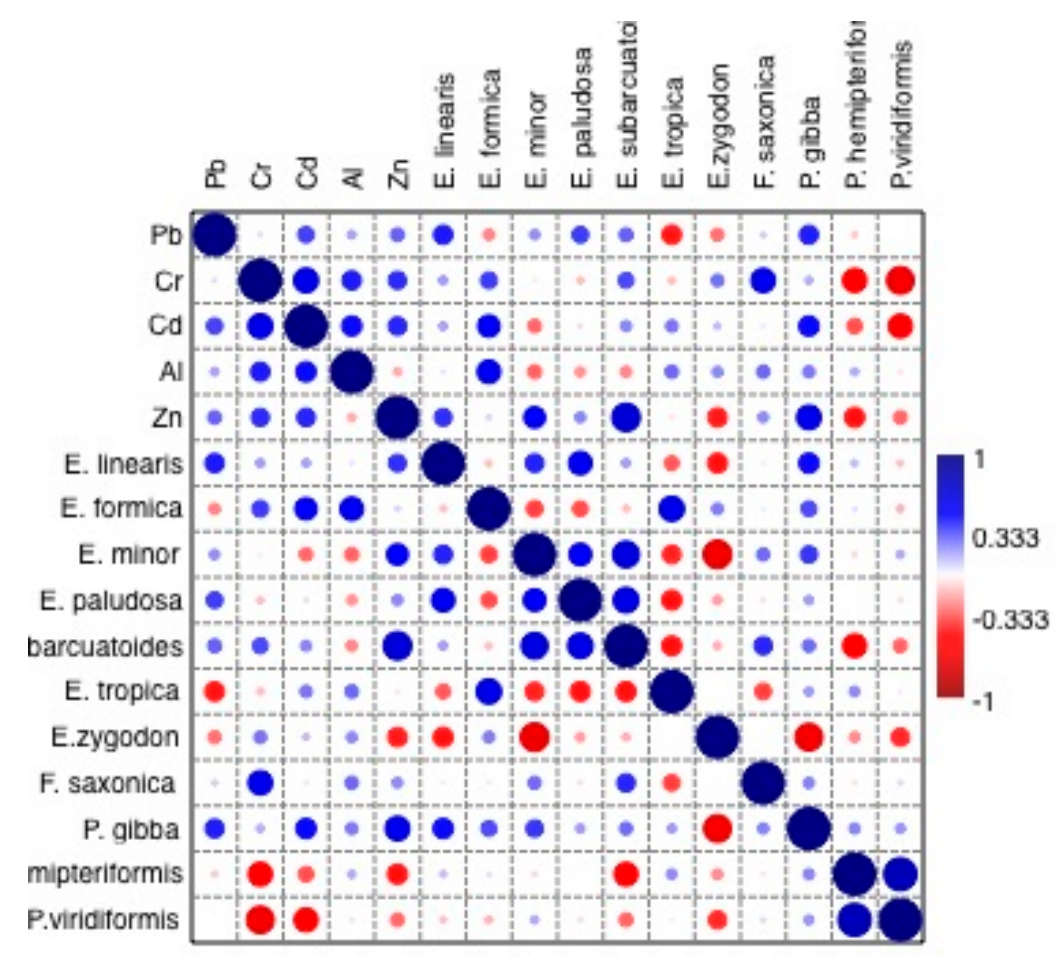

Figure 4. Pearson's correlation coefficients (r) of heavy metals in the sediment.

\subsection{Correlation between Diatom Assemblages and Metal Concentrations}

The spatial relationships between the metals within the core were examined by means of Pearson's correlation analysis (Figure 3). Pearson's correlation was also used to highlight the relationship between the total abundance of diatoms and the environmental parameters. Statistically significant correlations were observed between $\mathrm{Cr}$ and $\mathrm{Cd}(\mathrm{r}=0.58, p<0.01)$ $\mathrm{Zn}$ and $\mathrm{Al}(\mathrm{r}=0.55, p<0.01)$ and between $\mathrm{Cd}$ and $\mathrm{Al}(\mathrm{r}=0.47, p<0.01)$. The correlation between $\mathrm{Cd}$ and $\mathrm{Cr}$ declined in diatom Zones 3 and 4 (towards the surface) as shown in Figure 4.

Diatom species and environmental variables were analyzed using Pearson's correlation, where a significant correlation at level $p<0.05$ was observed among most of the environmental variables and diatom species. Chromium significantly correlated with $F$. saxonica (0.56) but negatively correlated with $P$. hemipteriformis $(-0.56)$ and $P$. viridiformis (-0.64). Zinc correlated significantly with E. subarcuoides (0.66) and Pinnularia Gibba (0.579). Strong and significant correlations were also observed between most diatom species. $E$. subarcoides significantly correlated with E. minor, both of which have greater linkages to $\mathrm{pH}$ and have similar auto-ecology preferences.

\section{Discussion}

\subsection{Implications of Spatiotemporal Variations in Diatoms}

The abundance and species of diatoms varied vertically, and therefore through time, within the $150-\mathrm{cm}$ core. Acidophilous and epiphytic diatom species, mainly from the genera Eunotia (28 taxa) and Pinnularia (17 species), were mostly associated with peat samples in the core, although not present in every sample. Overall, the sediment core was characterized by diatoms that are tolerant of a wide range of $\mathrm{pH}$ conditions. Changes in $\mathrm{pH}$ may be caused, in part, by seasonal variations in the delivery of alkaline waters to the acidic lake, thereby neutralizing the water's $\mathrm{pH}$. Therefore, hydrological changes in the water body can temporarily become neutral or acidic, resulting in vertical variations in diatom species in the lake core. The abundances of Eunotia, in fact, can be used as an indicator of $\mathrm{pH}$ fluctuations (Table 1). In addition, the expansion of acidophilous taxa such as Eunotia paludosa and acidobiontic species such as Eunotia exigua (found in Lake Telaga 
Pengilon) become common at $\mathrm{pH}$ values less than 5.5. As the $\mathrm{pH}$ drops to 4.5 these taxa begin to replace acidophilous taxa in the assemblage. Benthic and epiphytic diatoms were also present, and are general indicators of the water level.

Signs of acidification within the core occur in the lower most sediments of the core (diatom Zone I) and the surface layer $(0 \mathrm{~cm})$, both of which are dominated mostly with acidophilus taxa. In general, changes in Zone I were characterized by planktonic diatom that can tolerate $\mathrm{pH}$ values of 5.8 that decreased in response to a decrease in $\mathrm{pH}$. Acidification below a pH 5.5 led to the decline in species indicators of circumneutral water, such as Achnanthes Cymbella, Pinnularia microstauron, and Navicula hemansoides.

In Indonesia, previous studies have reported E. monodon var. tropica (Lange-Bertalot) from Lake Toba (Sumatra) [45], Borneo (Kalimantan) [46], and Papua [47]. In addition, Glushchenko and Kulikovskiy [48] reported E. monodon var. tropica (Lange-Bertalot) in southeastern Vietnam. The abundance of this species is generally regarded as an indicator of warm temperatures. Indonesia is considered a suitable environment due to the high average temperature conditions needed for E. monodon var. tropica, whereas the abundance of $B$. brebissonii (Ross) may indicate variations in $\mathrm{pH}$ at the coring site.

In contrast, Zone III was dominated by E. formica (Ehrenberg), a periphytic species that can tolerate acidic conditions (i.e., a pH range between 4.7 to 7.3) [49,50], but which is mostly characterized by neutral to slightly alkaline diatoms. Thus, diatom species in Zone III are indicators of both dystrophic and oligotrophic lake conditions, with an optimal $\mathrm{pH}$ of around 6.7. The increasing number of periphytic taxa in the sediments of Zone III is likely to indicate a concurrent increase and expansion of aquatic plants close to the core site, and an increase in shade caused by the plant cover $[47,51]$.

Zone IV, was dominated with Eunotia and has been found in the acidic environment of lake Telaga Pengilon, characterized by a pH of less than 3.5. Data from this study shows that the diatom composition in the top sediment was dominated with species Eunotia bilunaris var. linearis, Eunotia muchopila, Eunotia curvata, Eunotia paludosa, Eunotia tropica, Eunotia incisa.

Table 1. Diatom species reported from Telaga Pengilon with a $\mathrm{pH}$ of less than 3.5 (the $\mathrm{pH}$ range was collected from the reference by Denicola [52]).

\begin{tabular}{cccc}
\hline Species & pH (Range) & Species & pH (Range) \\
\hline Achanthes lanceolata Lange Bertalot & $2.4-3.3$ & Gomphonema olivacoides Hantzsch & $3.1-3.2$ \\
Coconeis placentula Ehrenberg & $2.8-3.3$ & Gomphonema parvulum (Kützing) Kützing & $2.4-3.1$ \\
Diatoma tenuis Agardh & 3.3 & Gomphonema subtile Ehrenberg & $3.0-3.1$ \\
Eunotia bilunaris var. linearis (Okuno) Lange-Bertalot & $2.9-3.4$ & Hantzschia amphioxys (Ehrenberg) Grunow & $2.8-3.5$ \\
Eunotia glacialis Meister & $1.8-3.5$ & Navicula crytochepala (Kützing) & $3.0-3.4$ \\
Eunotia minor (Kützing) Grunow & 3 & Nitzschia Linearis (Agardh) W.Sm. & $2.8-3.2$ \\
Eunotia monodon Ehrenberg & $2.9-3.4$ & Nitzschia palea (Kutzing) W. Smith & $1.8-3.4$ \\
Eunotia pectinalis (Ralfs) Rabenhorst & $2.8-3.4$ & Pinnularia borealis Ehrenberg & $2.8-3.3$ \\
Eunotia steineneckii Peterson & $3.0-3.1$ & Pinnularia major (Kützing) Rabenhorst & 3.2 \\
Fragilaria construens Marciniak & 3.2 & Pinnularia subcapitata W. Gregory & $3.0-3.4$ \\
Gomphonema angustatum (Kutzing) Rabenhorst & 3.3 & Eunotia bilunaris var. linearis Nitzsch & $3.2-3.4$ \\
\hline
\end{tabular}

In combination, these data are suggestive of relatively high water levels during the deposition of Zone III, although seasonal variations that induced short-term variations in $\mathrm{pH}$ were likely (as indicated by the presence of low $\mathrm{pH}$ tolerant species, Table 1). We believe that these variations primarily reflect (1) variations in inter-annual precipitation and evaporation which are known to influence $\mathrm{pH}$ in the lakes, and (2) water levels in the lakes, particularly high levels that allow hydrologic communication between the lakes via the small channel that traverses the sill. During high water levels, not only does $\mathrm{pH}$ increase, but the $\mathrm{pH}$ of lake Telaga Warna is moderated by the dilutional effects of the near-neutral conditions observed in lake Telaga Pengilon. Moreover, during high water levels, the sill area is transformed into a wetland-like area. Put differently, diatoms at the 
core site appear to reflect the combined variations in water levels and $\mathrm{pH}$ throughout the entire depositional period.

The abundance of E. bilunaris var. linearis (Ehrenberg) is associated with dystrophic waters and increased concentrations of sulfate. It is also an indicator of less polluted environments [53-55]. E. bilunaris var. linearis (Ehrenberg) was often attached to Bryophyta in an acidic mountain lake. The optimum $\mathrm{pH}$ for E. bilunaris var. linearis (Ehrenberg) is around $3.3-5.3[53,56]$.

The diatoms at the bottom of Zone II are characterized by broken frustules. Broken frustules are generally caused by dissolution and physical fragmentation. In this case, the vertical contrast in the nature of the frustules (intact vs. broken) between Zone II and the overlying and underlying zones could be due to differences in the depositional environment and or source of the diatoms. More specifically, we hypothesize that the diatom valves were fragmented by the volcanic activity, the broken frustule caused by their abrasion with volcanic sand-sized grains transported and deposited in the lake. There could also be time for frustules to partially dissolve in the water column prior to settling in the layer at a depth of $102 \mathrm{~cm}$.

Similar strata containing broken frustules were found in Rawa Danau (West Java, Indonesia) at a depth of around $50-125 \mathrm{~cm}$, which dated to ca. 181-80 years B.P. [57]. In this case, water levels in the lake decreased, thereby initiating pedogenesis. In addition, the volcanic activity significantly changed the composition and influx of sediment and broke the diatom frustule apart within this stratigraphic layer. Research by [45], who conducted a biostratigraphic study at lakes Telaga Cebong and Telaga Balekambang near lake Telaga Pengilon, found tephra in the strata located at a depth of $477-478 \mathrm{~cm}$. These sediments were also devoid of pollen. In combination, the data are suggestive of volcanic activity in the Dieng plateau that correlated with the deposition of lower Zone II sediments. Dieng has, in fact, a history of intermittent, geologically recent, volcanic eruptions. There have been 31 eruptions in Dieng during the Holocene, at least eight of which caused fatalities. The historical eruptions that occurred within the Dieng plateau have been dominated by phreatic eruptions and the emission of poisonous gases since 1375. In 1786, ground fissuring destroyed the village of Jamping killing 38 people. Eruptions in 1826 and 1827 caused several fatalities [45]. Further eruptions occurred in 1944, 1945, 1964, 1979, 2003, 2009, and 2017. The eruption of Sinila crater in 1979 included $\mathrm{CO}_{2}$ emissions, whereas the 1979 eruption of Timbang crater included high concentrations of $\mathrm{CO}_{2}$ and a volcanic induced earthquake. The lethal volcanic gases occurred when magma passed through a weaker zone of faulting and was trapped by a clayed layer of an altered ash pyroclastic fall deposit [58].

Supporting the above hypothesis is the occurrence of species that are suggestive of an increase in lake nutrients associated with vegetation following the deposition [59] of the lower Zone II sediments. Fragillaria in Zone III, for example, has commonly been recognized as pioneering taxa and represents a successional stage that frequently follows an eruption.

\subsection{Spatiotemporal Variations in Metals}

Lake bed sediments commonly serve as significant sinks for both major and trace metals, and have been extensively used to assess variations in contaminant loadings to lacustrine systems, particularly from anthropogenic sources [60]. In this study, three sources of $\mathrm{Cd}, \mathrm{Cr}, \mathrm{Pb}$, and $\mathrm{Zn}$ were initially hypothesized: (1) The potential influx of metals from hydrothermal zones of mineralization, (2) sediments from volcanic eruptions, and (3) the erosion of hillslope soils, particularly in response to recent agricultural activity, which may have been amended by Zn containing fertilizers.

Pearson's correlation analysis of the metals, combined with the PCA, suggests that in the lower deposits (diatom Zones I and II), $\mathrm{Cd}$ and $\mathrm{Cr}$, and to a lesser degree, $\mathrm{Pb}$ and $\mathrm{Zn}$ were derived from a similar source. Both $\mathrm{Pb}$ and $\mathrm{Zn}$ are commonly associated with one another in hydrothermal ore bodies, and $\mathrm{Cd}$ often follows $\mathrm{Zn}$ in these types of geological 
materials. In addition, water-rock interactions under acidic conditions may enrich rockderived elements in lake bed sediments, including, for example, those examined herein [61]. It is interesting to note, however, that all four elements exhibited maximum concentrations at the top of Zone I and within the bottom sediments of Zone II (Figure 2). As noted above, the diatoms in Zone II were characterized by broken frustules, suggestive of a volcanic eruption. Thus, we believe that the increase in metal concentrations is reflective of the input of volcanic materials to the lake from an eruption during the deposition of upper Zone I and lower Zone II sediments.

Figure 2, and the PCA, show that spatial variations between $\mathrm{Cd}, \mathrm{Cr}, \mathrm{Zn}$, and $\mathrm{Pb}$ differ between Zones I/II and Zones III/IV. These differences may reflect changes in the predominant source(s) of the metals. Inputs from hillslope erosion were postulated as a possible source of the metals. The erosion rates in the Dieng plateau in general are very high, exceeding 480 tons/ha/year and are exacerbated by high intensity rainfall during the rainy season. The total rainfall in the region ranges between $2500-3500 \mathrm{~mm} /$ year in the Dieng plateau [62,63]. However, the agricultural activity within the Telaga Warna and Telaga Pengilon lake basins has remained limited to date, suggesting that the impacts of hillslope erosion on lake water and sediment quality may be relatively minor.

Aluminum was analyzed here as a potential indicator of hillslope erosion as $\mathrm{Al}$ oxides/hydroxides is an important component of the areas upland soils, and it is associated with clay minerals (which are abundant in the soil's B-horizon). However, $\mathrm{Al}$ and the other elements lacked a pronounced increase in metal concentrations towards the surface of the core, suggesting that the hillslope erosion has not had a significant effect on metal concentrations. This is consistent with the fact that there is not a lot of agriculture in the lake basin.

Conservation and forest restoration activities in the Telaga Warna and Telaga Pengilon lake basins, which uses endemic species (Altingiaceae, Burseraceae, Cannabaceae, Cunoniaceae, Ericaceae, Fagaceae, Hamamelidaceae, Juglandaceae, and Phyllanthaceae), has been going on for 3 years, from 2015-2017. During 2015, the governments performed reforestation using 85 species of tree to protect the area around Telaga Warna and Telaga Pengilon. The reforestation efforts planted 950 seedlings in an area of \pm 2.56 ha in order to protect Telaga Pengilon from potato farming around Dieng and to increase the vegetation cover [64].

\section{Conclusions}

This study examines the spatiotemporal distribution of diatoms and selected metals in a core extracted from a sill between two contrasting lakes, including $\mathrm{Pb}, \mathrm{Cd}, \mathrm{Cr}, \mathrm{Zn}$, and $\mathrm{Al}$ to gain sights into change in the lakes' aquatic conditions. The conclusions are summarized as follows:

(1) The high abundance of acid-tolerant Eunotia species throughout the core indicate that $\mathrm{pH}$ fluctuated at the coring site. The observed variations in $\mathrm{pH}$ were presumably related to the influence of water level fluctuations at the coring site in response to both seasonal and inter-annual variations in precipitation. Variations in water levels were also likely to result in differences in the amount of hydrologic mixing between lake waters. During periods of low water, more acidic conditions characterized by minimal lake water mixing was likely. During higher water levels, $\mathrm{pH}$ was likely to increase, in part due to the mixing of the acidic waters in lake Telaga Warna with the higher $\mathrm{pH}$ waters in lake Telaga Pengilon.

(2) The occurrence of diatoms with broken frustules at the bottom of Zone II with relatively high peak metal concentrations of $\mathrm{Cd}, \mathrm{Cr}, \mathrm{Pb}$, and $\mathrm{Zn}$ at the top of Zone I and the bottom of Zone II suggest that lake conditions were impacted by the input of volcanic debris from a local eruption. This argument is supported by diatom assemblages found in the sediments overlying Zone II, which includes pioneering species that are known to follow eruptions in the area. 
(3) Metal concentrations, including $\mathrm{Al}$, did not increase towards the surface of the sediments, suggesting that recent agricultural activities and the associated impact on hillslope soil erosion has not significantly impacted the lakes. This is not surprising given that in contrast to adjacent areas, the lake basin is located in a protected conservation area that is not extensively farmed.

\begin{abstract}
Author Contributions: Conceptualization, T.R.S. and J.R.M.; methodology, T.R.S. and J.R.M.; software, K.S.; validation, K.S., T.R.S., J.J., and R.H.; formal analysis, K.S.; investigation, K.S.; resources, K.S. and R.H.; data curation, K.S.; writing—original draft preparation, K.S.; writing—review and editing, K.S.,T.R.S., and J.R.M.; visualization, K.S. and J.J.; supervision, T.R.S.; project administration, R.H.; funding acquisition, T.R.S. All authors have read and agreed to the published version of the manuscript.

Funding: This research was funded by the Research Grant of Penelitian Terapan Unggulan Perguruan Tinggi (PTUPT) number 101-120/UN7.P4.3/PP/2018, Directorate Research and Community Services, Directorate General Research and Development, The Indonesian Ministry of Research, Technology, and Higher Education.
\end{abstract}

Data Availability Statement: Not applicable.

Acknowledgments: This study was made possible by funding from the Global Innovation Initiative Grant that supported an exchange student to Western Carolina University, USA. The authors thank Kelly Ferri, Muhammad Hadi Al Amien, Alam Dilazuardi, and Geyga Pamrayoga for their support in conducting field and laboratory works.

Conflicts of Interest: The authors declare no conflict of interest.

\title{
References
}

1. Zaennudin, A. The characteristic of eruption of Indonesian active volcanoes in the last four decades. J. Lingkung. Bencana Geol. 2010, 1, 113-129.

2. Edmonds, M.; Grattan, J.; Michnowicz, S. Volcanic gases: Silent killers. In Observing the Volcano World; Fearnley, C.J., Bird, D.K., Haynes, K., McGuire, W.J., Jolly, G., Eds.; Advances in Volcanology (An Official Book Series of the International Association of Volcanology and Chemistry of the Earth's Interior-IAVCEI); Springer: Barcelona, Spain, 2015; pp. 65-89.

3. Soeprobowati, T.R.; Suedy, S.W.A.; Hadiyanto. Diatoms and water quality of Telaga Warna Dieng, Java Indonesia. In Proceedings of the 2nd International Conference on Tropical and Coastal Region Eco Development, IOP Conference Series: Earth and Environmental Science, Bali, Indonesia, 25-27 October 2016; Volume 55, pp. 1-6.

4. Balai Konservasi Sumber Daya Alam. Rencana Pengelolaan Jangka Panjang Taman Wisata Alam Telogo Warno Telogo Pengilon Periode 2013 Sampai Dengan 2022 Provinsi Jawa Tengah; Kementrian Kehutanan Direktorat Jendral Perlindungan Hutan dan Konservasi Alam: Semarang, Indonesia, 2021; Unpublished Work.

5. Soeprobowati, T.R.; Suedy, S.W.A.; Hadiyanto; Lubis, A.A.; Gell, P. Diatom assemblage in the $24 \mathrm{~cm}$ upper sediment associated with human activities in Lake Warna Dieng Plateau Indonesia. Environ. Technol. Innov. 2018, 10, 314-323. [CrossRef]

6. Soeprobowati, T.R.; Jumari; Hariyati, R.; Gell, P. Paleolimnology record of human impact on a lake ecosystem: The case of shallow lakes in Central Java. In IOP Conference Series: Earth and Environmental Science; IOP Publishing: Bristol, UK, 2019; Volume 276, p. 012015.

7. Sari, K.; Hidayat, J.W.; Soeprobowati, T.R. Community structure and species diversity of Diatom in area between Telaga Warna and Telaga Pengilon, Indonesia. Int. Res. J. Environ. Sci. 2018, 7, 1-6.

8. Hermawan, H.; Priato, E.; Setyowati, E. Evaluasi termal ruang luar desa wisata Dieng Wonosobo. J. Penelit. Pengabdi. Kpd. Masy. 2014, 2, 115-122.

9. Harriyadi, H. Pertimbangan pemilihan lokasi kompleks Candi Dieng. J. Penelit. Pengemb. Arkeol. 2019, 37, 123-138. [CrossRef]

10. Pradana, A.; Sara, F.H.; Wahdaningrum, W. The analysis of environmental degradation and carica agroforestry system as an attempt of environmental restoration in Dieng Plateau. Int. J. Environ. Sci. Dev. 2015, 6, 861. [CrossRef]

11. Nurfahma, P.; Malika, R.F.; Saria, R.P.; Nurkholis, A. Influence of local wisdom to prevent disappearance of Cebong Lake in Sembungan village, Wonosobo district. In Proceedings of the International Conference on Appropriate Technology Development, Bandung, Indonesia, 5-7 October 2015; pp. 165-168. [CrossRef]

12. Supriyanto, H.; Lestari, S. Danau-danau volkanik di Dataran Tinggi Dieng: Pemanfaatan dan Masalah Lingkungan Hidup yang Dihadapi. Teknosains 2015, 5, 36-48.

13. Lastiantoro, C.Y.; Putra, P.B.; Andy, C.S. Dampak Penyedotan Air Telaga Dalam Usaha Tani Kentang di Telaga Pengilon Dieng Wonosobo; Muhammadiyah University Press: Surakarta, Indonesia, 2017; pp. 241-254.

14. Pudjiastuti, H. Impacts of agricultural practices and tourism activities on the sustainability of Telaga Warna and Telaga Pengilon Lakes, Dieng Plateau, Central Java. In Proceedings of the 2nd International Conference on Energy, Environmental and Information System ICENIS, Semarang, Indonesia, 15-16 August 2018; Volume 31, pp. 1-6. [CrossRef] 
15. Liu, W.; Ma, L.; Abuduwaili, J. Anthropogenic influences on environmental changes of lake Bosten, the largest inland freshwater lake in China. Sustainability 2020, 12, 711. [CrossRef]

16. Mitchelutti, N.; Wolfe, A.P.; Cooke, C.A.; Hobbs, W.O.; Vuille, M.; Smol, J.P. Climate change forces new ecological states in tropical andean lakes. PLOS ONE 2015, 10, e0115338. [CrossRef]

17. Smol, J.P. Pollution of Lakes and Rivers a Paleoenvironmental Perspective, 2nd ed.; Blackwell Publishing: Hoboken, NJ, USA, 2008.

18. Bellinger, E.G.; Sigee, D.C. Freshwater Algae: Identification and Use as Bioindicators; John Wiley \& Sons Ltd.: Chichester, UK, 2010.

19. Pardo, I.; Delgado, C.; Abraín, R.; Gómez-Rodríguez, C.; García-Roselló, E.; García, L.; Reynoldson, T.B. A predictive diatom-based model to assess the ecological status of streams and rivers of northern Spain. Ecol. Indic. 2018, 170, 519-528. [CrossRef]

20. Nhiwatiwa, T.; Dalu, T.; Sithole, T. Assessment of river quality in a subtropical Austral river system: A combined approach using benthic diatoms and macroinvertebrates. Appl. Water Sci. 2017, 7, 4785-4792. [CrossRef]

21. Sonneman, J.A.; Walsh, C.J.; Breen, P.F.; Sharpe, A.K. Effects of urbanization on streams of the Melbourne region, Victoria, Australia. II. Benthic diatom communities. Freshw. Biol. 2001, 46, 553-565. [CrossRef]

22. Khudher, E.K.; Al-Jasimee, A.S. Diatoms (Bacillariophyta) as bio-indicators. Int. J. Res. Pharm. Sci. 2019, 10, 1562-1565. [CrossRef]

23. Potapova, M.; Charles, D.F. Diatom metrics for monitoring eutrophication in rivers of the United States. Ecol. Indic. 2007, 7, 48-70. [CrossRef]

24. Szczepocka, E.; Zeelazna-Wieczorek, J. Diatom biomonitoring-Scientific foundations, commonly discussed issues and fre-quently made errors. Oceanol. Hydrobiol. Stud. 2018, 47, 314-325. [CrossRef]

25. Feret, L.; Bouchez, A.; Rimet, F. Benthic diatom communities in high altitude lakes: A large scale study in the French Alps. Ann. Limnol. Int. J. Limnol. 2017, 53, 411-423. [CrossRef]

26. Harding, W.R.; Taylor, J.C. Diatoms as Indicators of Historical Water Quality: A Comparison of Samples Taken in the Wem-mershoek Catchment (Western Province, South Africa) in 1960 and 2008; Water Research Commission: Pretoria, South Africa, 2014; pp. 601-606.

27. Allard, P.; Dajlevic, D.; Delarue, C. Origin of carbon dioxide emanation from the 1979 Dieng eruption, Indonesia: Implications for the origin of the 1986 Nyos catastrophe. J. Volcanol. Geotherm. Res. 1989, 39, 195-206. [CrossRef]

28. Van Bergen, J.M.; Alain, B.; Sri, S.; Terry, S.; Kastiman, S. Crater Lakes of Java: Dieng, Kelud, Ijen-Excursion Guidebook; IAVCEI General Assembly: Bali, Indonesia, 2000.

29. Battarbee, R.W.; Kernan, M.; Livingstone, D.M.; Nickus, U.; Verdonschot, P.; Hering, D.; Moss, B.; Wright, R.F.; Evans, C.D.; Grimalt, J.O.; et al. Freshwater ecosystem responses to climate change: The Euro-Limpacs Project. In The Water Framework Directive-Ecological and Chemical Status Monitoring; Quevauviller, P., Borchers, U., Thompson, C., Simonart, T., Eds.; John Wiley \& Sons: Hoboken, NJ, USA, 2009; pp. 313-354.

30. Krammer, K.; Lange-Bertalot, H. Bacillariophyceae 1. Teil: Naviculaceae. In Süsswasserflora von Mitteleuropa, Band 2/1; Ettl, H., Gärtner, G., Gerloff, J., Heynig, H., Mollenhauer, D., Eds.; Gustav Fischer Verlag: Jena, Germany, 1986; pp. 1-876.

31. Krammer, K.; Lange-Bertalot, H. Bacillariophyceae 2. Teil: Bacillariaceae, Epithemiaceae, Surirellaceae. In Süsswasserflora von Mitteleuropa, Band 2/2; Ettl, H., Gärtner, G., Gerloff, J., Heynig, H., Mollenhauer, D., Eds.; Gustav Fischer Verlag: Jena, Germany, 1988; pp. 1-596.

32. Krammer, K.; Lange-Bertalot, H. Bacillariophyceae 3. Teil: Centrales, Fragilariaceae, Eunotiaceae. In Süsswasserflora von Mitteleropa; Ettl, H., Gerloff, J., Heynig, H., Mollenhauer, D., Eds.; Gustav Fischer Verlag: Jena, Germany, 1991; pp. 1-576.

33. Krammer, K.; Lange-Bertalot, H. Bacillariophyceae 4. Teil: Achnanthaceae, Kritische Erganzungen zu Navicula (Lineolatae), Gomphonema Gesamtliteraturverzeichnis Teil 1-4 [second revised edition] [With "Ergänzungen und Revisionen" by H. Lange Bertalot]. In Suesswasserflora von Mitteleuropa; Ettl, H., Ed.; Spektrum Akademischer Verlag: Heidelberg, Germany, 2004; Volume 2, pp. 1-468.

34. Krammer, K.; Lange-Bertalot, H. Bacillariophyceae 5. Teil: Bacillariophyceae. In Süsswasserflora von MitteleuropaII; Springer Spektrum Verlag: Jena, Germany, 2000; Volume 2, pp. 1-311.

35. Taylor, J.C.; Harding, W.R.; Archibald, C.G.M. An Illustrated Guide to Some Common Diatom Species from South Africa; Water Research Commission: Pretoria, South Africa, 2007; pp. 1-225.

36. Gell, P.; Tibby, J.; Fluin, P.; Leahy, M.; Reid, K.; Adamson, S.; Bulpin, A.; Macgregor, P.; Wallbrink, G.; Hancock; et al. An Illustrated Key to Common Diatom Genera from Southern Australia; CRC for Freshwater Ecology: Thurgoona, Australia, $1999 ;$ pp. 1-68.

37. Sonneman, J.A. An Illustrated Guide to Common Stream Diatom Species from Temperate Australia; Cooperative Research Centre for Freshwater Ecology: Hurgoona, Australia, 2000; pp. 11-168.

38. Bahls, L.L. Diatoms from Western North America 1. Some New and Notable Biraphid Species; Montana Diatom Collection; Lubrecht \& Cramer: Helena, MT, USA, 2017; pp. 1-52.

39. Bahls, L.; Boynton, B.; Johnston, B. Atlas of diatoms (Bacillariophyta) from diverse habitats in remote regions of western Canada. PhytoKeys 2018, 1-186. [CrossRef]

40. Guiry, M.D.; Guiry, G.M. AlgaeBase. World-Wide Electronic Publication, National University of Ireland, Galway. Available online: https:www.algaebase.org (accessed on 10 August 2020).

41. Juggins, S. C2 Software for Ecological and Palaeoecological Data Analysis and Visualization; Version 1.7.7; University of New Castle: New Castle, UK, 2016; Available online: https://www.sta.ncl.ac.uk/stephen.juggins/software/C2Home.htm (accessed on 28 October 2020). 
42. Oksanem, F.; Guillaume, B.; Roeland, K.; Legendre, P.; Minchin, P.R.; O’hara, R.B.; Simpson, G.K.L.; Solymos, P.; Henry, M.H.; Wagner, S.; et al. Vegan: Community Ecology Package, R Package Version 2.0-10. 2013. Available online: http:/ /CRAN.R-project.org/package=vegan (accessed on 21 December 2020).

43. Ter Braak, C.J.F.; Juggins, S. Weighted averaging partial least squares regression (WA-PLS): An improved method for reconstructing environmental variables from species assemblages. In Twelfth International Diatom Symposium, Developments in Hydrobiology; Van Dam, H., Ed.; Springer: Dordrecht, The Netherlands, 1993; Volume 90, pp. 485-502.

44. Hammer, O. PAST: Paleontological Statistics Software Package for Education and Data Analysis. Version 2.17c. 2017. Available online: http:/ / priede.bf.lu.lv/ftp/pub/TIS/datu_analiize/PAST/2.17c/download.html (accessed on 26 December 2020).

45. Hustedt, F. Systematische und ökologische untersu-chungen über die diatomeen-flora von Java, Bali und Sumatra nach dem material der deutschen limnologischen Sunda-Expedition. Arch. Hydrobiol. Suppl. 1937, 15, 187-296.

46. Schmidt, A. Atlas der Diatomaceen-Kunde 1874-1959; O.R. Reisland: Leipzig, Germany, 1909; pp. 1-120.

47. Vyverman, W. Diatoms from Papua New Guinea. Bibl. Diatomol. 1995, 22, 1-244.

48. Glushchenko, A.M.; Kulikovskiy, M.S. Taxonomy and distribution of the genus Eunotia Ehrenberg in water ecosystems of Vietnam. Inland Water Biol. 2017, 10, 130-139. [CrossRef]

49. Taylor, J.C.; Cocquyt, C.; Mayama, S. Navicula nielsfogedii sp. nov; A new diatom (Bacillariophyta) from tropical and sub-tropical Africa. Fottea 2016, 16, 201-208. [CrossRef]

50. Geo Dipa Energi. INO: Geothermal Power Development Project-Dieng Unit 2 Project Component; Initial Environmental Examination; INO: Plymouth Meeting, PA, USA, 2019; pp. 1-195.

51. Pudjoarianto, A.; Cushing, E.J. Pollen-stratigraphic evidence of human activity at Dieng, Central Java. Palaeogeogr. Palaeoclimatol. Palaeoecol. 2001, 171, 329-340. [CrossRef]

52. DeNicola, D.M. A review of diatoms found in highly acidic environments. Hydrobiologia 2004, 433, 111-122. [CrossRef]

53. De Faria, D.M.; Guimarães, A.T.B.; Ludwig, T.A.V. Responses of periphytic diatoms to mechanical removal of Pistia stratiotes L. in a hypereutrophic subtropical reservoir: Dynamics and tolerance. Braz. J. Biol. 2013, 73, 681-689. [CrossRef]

54. Cruches, F.; Urrutia, R.; Parra, O.; Araneda, A.; Treutler, H.; Berttrand, S.; Fagel, N.; Torres, L.; Barra, R.; Chirimos, L. Change in diatom assemblages in an Andean lake in response to a recent volcanic event. Arch. Hydrobiol. 2006, 165, 23-25. [CrossRef]

55. Sajekti, A.S. An Indication of Holocene Environmental Change Based on the Palynological Research in Telaga Cebong, Dieng Plateau, Central Java, Indonesia; Muséum national d'Histoire naturelle: Paris, France, 2009; pp. 1-93.

56. Alles, E.; Nörpel-Schempp, M.; Lange-Bertalot, H. Taxonomy and ecology of characteristic Eunotia species in headwaters with low electric conductivity. Nova Hedwig. 1991, 53, 171-213.

57. Puussepp, L.; Kangur, M. Linking diatom community dynamics to changes in terrestrial vegetation: A palaeolimnological case study of Lake Kūži, Vidzeme Heights (Central Latvia). Est. J. Ecol. 2010, 59, 259-280. [CrossRef]

58. Newhall, C.G.; Dzurisin, D. Historical Unrest at Large Calderas of the World; Technical Report 1855; Department of the Interior, US Geological Survey: Washington, DC, USA, 1988; pp. 1-1108.

59. Burge, D.R.L. Relations of Water Quality, Land Use Buffers, and Diatom Communities of Connected Depressions within the Cache River Watershed, Arkansas, USA. Master's Thesis, Arkansas State University, Jonesboro, AR, USA, 2019 ; pp. 1-142.

60. Miller, J.R.; Mackin, G.; Orbock Miller, S.M. Application of Geochemical Tracers to Fluvial Sediment; Springer: Cham, Switzerland, 2015; pp. 1-142.

61. Fan, Z.; Wang, W.; Tang, C.; Li, Y.; Wang, Z.; Lin, S.; Zeng, F. Targeting remediation dredging by ecological risk assessment of heavy metals in lake sediment: A case study of Shitang Lake, China. Sustainability 2019, 11, 7251. [CrossRef]

62. Haryono, S.; Mulyana, A.R.; Subagyo, A. Application of SABO technique in controlling the water destructive force in dataran tinggi Dieng. J. Tek. Hidraul. 2012, 3, 157-168.

63. Nugraha, S.B.; Akhsin, W.; Benardi, A.I. Pemanfaatan teknologi sig untuk pemetaan tingkat ancaman longsor di Kecamatan Kejajar, Wonosobo. J. Geogr. 2015, 12, 203-221.

64. Mardiatno, D. Teknik Transplanting Tanaman Hutan; Balai Penelitian dan Pengembangan Teknologi Pemgelolaan Daerah Aliran Sungai. 2018; Volume 4, p. 2. Available online: https:/ / www.forda-mof.org/files/Majalah_Cerdas_Vol_4_No_2_Oktober_2018 .pdf (accessed on 17 March 2021). 